\title{
Kształtowanie przestrzeni - sprawny system czy chaos? Miejscowy plan zagospodarowania przestrzennego - przeznaczenie terenów
}

\author{
Anna Wieczorek
}

\section{STRESZCZENIE}

Artykuł jest kolejnym z serii artykułów o systemie kształtowania przestrzeni w Polsce i drugim z trzech dotyczacych zakresu stanowienia miejscowego planu zagospodarowania przestrzennego. Jest uzupełnieniem i rozszerzeniem artykułu pt. Ksztattowanie przestrzeni - sprawny system czy chaos? Miejscowy plan zagospodarowania przestrzennego - zakres stanowienia. Odnosi się do kluczowego zagadnienia, jakim jest przeznaczenie terenu/ów. Wskazuje na wieloznaczność tego pojęcia, a tym samym mało precyzyjny zakres stanowienia planów miejscowych.

Świadomie powtórzono niektóre fragmenty artykułu pt. Kształtowanie przestrzeni - sprawny system czy chaos? Miejscowy plan zagospodarowania przestrzennego - zakres stanowienia.

Osobom, które go nie czytały, ułatwi to zrozumienie zagadnień omawianych w niniejszym artykule.

W celu zachowania precyzji wypowiedzi posłużono się szeregiem cytatów. Artykuł oparto na przepisach prawa obowiązujących na koniec października 2021 r.

Słowa kluczowe: miejscowy plan zagospodarowana przestrzennego, przeznaczenie terenów

\section{Wprowadzenie}

Podstawa kształtowania przestrzeni w gminach są miejscowe plany zagospodarowania przestrzennego, w skrócie plany miejscowe, będące aktami prawa miejscowego. Ich zakres stanowienia określa ustawa o planowaniu i zagospodarowaniu przestrzennym (upzp).

Artykuł jest kolejnym z serii artykułów o systemie kształtowania przestrzeni w Polsce i drugim z trzech dotyczacych zakresu stanowienia planów miejscowych. Jest uzupełnieniem i rozszerzeniem artykułu pt. Ksztattowanie przestrzeni - sprawny system czy chaos? Miejscowy plan zagospodarowania przestrzennego - zakres stanowienia. Odnosi się do kluczowego zagadnienia, jakim jest przeznaczenie terenu/ów. Wskazuje na wieloznaczność tego pojęcia i potwierdza tezę o braku precyzji zakresu stanowienia planów miejscowych.

Pojęcie przeznaczenie terenu/ów nie zostało zdefiniowane w ustawie o planowaniu i zagospodarowaniu przestrzennym. W rozporzadzeniu w sprawie wymaganego zakresu projektu miejscowego planu zagospodarowania przestrzennego (rozp. mpzp) napisano jedynie, że „ustalenia dotyczące przeznaczenia terenów powinny zawierać określenie przeznaczenia poszczególnych terenów" [§ 4 pkt 1 rozp. mpzp]. Rozporządzenie zawiera 
Załącznik nr 1 pt. „Podstawowe barwne oznaczenia graficzne i literowe dotyczące przeznaczenia terenów, które należy stosować na projekcie rysunku planu miejscowego (wzór)", (dalej Załącznik nr 1 do rozp. mpzp lub Załącznik nr 1). Użyte w Załączniku nr 1 nazwy terenów przesądzają o sposobie ich określania w planach miejscowych. Niestety nazwy są wieloznaczne, a w ustawie o planowaniu i zagospodarowaniu przestrzennym oraz w wydanych na jej podstawie przepisach wykonawczych brakuje potrzebnych definicji. Wyciag z Załącznika nr 1, zawierający wykaz wszystkich wymienionych w nim terenów oraz ich oznaczenia literowe umieszczono na końcu artykułu.

Z terenami wymienionymi w Załączniku nr 1 ma związek szereg przepisów odrębnych. Trudno jest podjąć decyzję, do którego z tych przepisów zastosować odesłanie, tym bardziej, że zawierają określenia bliskoznaczne.

Trzeba wyjaśnić, że sporządzający plan miejscowy ma prawo i obowiązek zdefiniowania niejednoznacznych określeń, jeśli ich definicji brakuje w ustawie o planowaniu i zagospodarowaniu przestrzennym i wydanych na jej podstawie przepisach wykonawczych. Stanowi o tym rozporządzenie w sprawie "Zasad techniki prawodawczej” (rozp.ztp). Należy zastosować odesłanie do definicji zawartych w przepisach odrębnych [§ 156 Załącznika do rozp. ztp], przy czym rozporządzenie nie przesądza, do którego przepisu odesłać, kiedy np. dwa przepisy definiują różnie to samo pojęcie. Nie wolno jedynie stosować odesłania do określenia bliskoznacznego. „Do oznaczenia jednakowych pojęć używa się jednakowych określeń, a różnych pojęć nie oznacza się tymi samymi określeniami.” [§ 10 Załącznika do rozp. ztp]. Jeżeli w przepisach odrębnych nie ma potrzebnej definicji, to można powołać normę, albo opracować „własną” definicję, opierając się np. na słownikach.

W powszechnym odczuciu mamy zbyt małe pokrycie kraju planami miejscowymi. Jedna z przyczyn takiego stanu rzeczy są kłopoty ze sporządzaniem tych planów spowodowane mało precyzyjnym zakresem ich stanowienia, w szczególności brakiem definicji użytych $\mathrm{w}$ nim pojęć w ustawie o planowaniu i zagospodarowaniu przestrzennym. Prowadzi to do sporów z organami nadzoru (wojewodami) i może skutkować stwierdzeniem nieważności uchwalonego planu miejscowego.

W artykule poddano analizie nazwy wszystkich terenów wymienionych w Załączniku nr 1 do rozp. mpzp. Natomiast nie jest przedmiotem artykułu analizowanie i ocenianie, jak rozumiane jest pojęcie przeznaczenie terenu/ów w obowiązujących planach miejscowych, orzecznictwie i rozstrzygnięciach nadzorczych wojewodów, literaturze dotyczącej zakresu stanowienia planu miejscowego oraz w dokumentach rządowych i sejmowych.

Dla zachowania precyzji wypowiedzi nazwy terenów z Załącznika nr 1 do rozp. mpzp przytoczono w formie cytatów. Ponadto posłużono się szeregiem cytatów z wybranych aktów prawa. 


\section{„Tereny zabudowy mieszkaniowej", „Tereny zabudowy usługowej" i „Tereny zabudowy techniczno-produkcyjnej" [Załącznik nr 1 do rozp. mpzp]}

Zabudowa - słowo, które powtarza się w nazwach terenów, nie doczekało się definicji w polskim systemie prawnym. $\mathrm{W}$ wydanym na podstawie ustawy Prawo budowlane $(\mathrm{uPb})$ rozporządzeniu w sprawie warunków technicznych jakim powinny odpowiadać budynki i ich usytuowanie (rozp.w.t.) występuje w zestawieniu z innymi określeniami: zabudowa śródmiejska, zabudowa jednorodzinna i zabudowa zagrodowa [§ 3 pkt 1, 2 i 3 rozp.w.t.].

Zabudowa śródmiejska, to „zgrupowanie intensywnej zabudowy na obszarze śródmieścia, określonej w miejscowym planie zagospodarowania przestrzennego, a w przypadku braku planu miejscowego w studium uwarunkowań i kierunków zagospodarowania przestrzennego gminy" [§ 3 pkt 1 rozp.w.t.].

Zabudowa jednorodzinna, to ,jeden budynek mieszkalny jednorodzinny lub zespół takich budynków, wraz z budynkami garażowymi i gospodarczymi” [§ 3 pkt 2 rozp.w.t.].

Zabudowa zagrodowa, to „w szczególności budynki mieszkalne, budynki gospodarcze lub inwentarskie w rodzinnych gospodarstwach rolnych, hodowlanych lub ogrodniczych oraz w gospodarstwach leśnych" [§ 3 pkt 3 rozp.w.t.].

Powyższe definicje wskazuja, że zabudowa to zespoły budynków, w tym budynki o znaczeniu podstawowym, np. mieszkalne i o charakterze pomocniczym np. garaże. Przez analogię, można przyjąć, że zabudowa usługowa, to budynki związane z wykonywaniem usług, a zabudowa techniczno-produkcyjna, to budynki związane z produkcją. Zespoły budynków uzupełniają niezbędne dla ich prawidłowego funkcjonowania dojścia, dojazdy, wodociagi, kanalizacja, miejsca do gromadzenia odpadów, ogrodzenia itp., czyli budowle, obiekty małej architektury i urządzenia budowlane, o których mowa w ustawie Prawo budowlane. Można wnioskować, że zabudowa oznacza zespoły budynków albo zespoły obiektów budowlanych. Wyjątkowo nieprecyzyjne określenie zabudowa śródmiejska nie ułatwia, a utrudnia ustalenie, co rozumieć pod tym pojęciem.

Budynki, budowle, obiekty małej architektury i urządzenia budowlane nie mają definicji w ustawie o planowaniu i zagospodarowaniu przestrzennym i wydanych na jej podstawie przepisach wykonawczych. Pojęcia te różnie definiuja przepisy odrębne.

Ustawa Prawo budowlane określa, czym sa obiekty budowlane (budynki, budowle i obiekty małej architektury), budynki, w tym budynki mieszkalne jednorodzinne, budowle, obiekty małej architektury oraz urządzenia budowlane [art. 3 pkt 1, pkt 2, pkt 2a, pkt 3, pkt 4 i pkt $9 \mathrm{uPb}$ ]. Ponadto przepis wykonawczy do ustawy Prawo budowlane - rozporzadzenie w sprawie warunków technicznych jakim powinny odpowiadać budynki i ich usytuowanie definiuje takie pojęcia, jak: budynek mieszkalny, budynek zamieszkania zbiorowego, budynek użyteczności publicznej, budynek rekreacji indywidualnej oraz budynek gospodarczy [§ 3 pkt 4, pkt 5, pkt 6, pkt 7 i pkt 8 rozp.w.t.].

Inaczej niż ustawa Prawo budowlane definiuje i grupuje budynki oraz inne obiekty budowlane rozporządzenie w sprawie Polskiej Klasyfikacji Obiektów Budowlanych (PKOB). Obiekty budowlane dzieli na budynki oraz obiekty inżynierii lądowej i wodnej. Nie odnosi 
się do obiektów małej architektury. Stosuje podstawowy podział budynków na mieszkalne i niemieszkalne.

Zgodnie z ustawą Prawo budowlane budynek mieszkalny jednorodzinny, to „budynek wolno stojący albo budynek w zabudowie bliźniaczej, szeregowej lub grupowej, służący zaspokajaniu potrzeb mieszkaniowych, stanowiący konstrukcyjnie samodzielną całość, w którym dopuszcza się wydzielenie nie więcej niż dwóch lokali mieszkalnych albo jednego lokalu mieszkalnego i lokalu użytkowego o powierzchni całkowitej nieprzekraczającej 30\% powierzchni całkowitej budynku" [art. 3 pkt $2 \mathrm{a} \mathrm{uPb}$ ]. Według rozporządzenia w sprawie warunków technicznych, jakim powinny odpowiadać budynki i ich usytuowanie budynek mieszkalny, to „budynek mieszkalny wielorodzinny” oraz „budynek mieszkalny jednorodzinny" [§ 3 pkt 4 rozp.w.t.]. Brak określenia czym jest budynek wielorodzinny.

PKOB dzieli budynki mieszkalne na budynki jednorodzinne (do których zalicza np.: leśniczówki, domki wypoczynkowe, domy letnie), budynki o dwóch mieszkaniach i wielomieszkaniowe oraz budynki zbiorowego zamieszkania, np. domy opieki społecznej. W PKOB nie ma budynków wielorodzinnych.

Jeszcze więcej problemów nastręcza ustalenie czym są obiekty budowlane, w tym budynki związane z wykonywaniem usług. Mogą to być budynki użyteczności publicznej [§ 3 pkt 6 rozp.w.t.] albo budynki handlowo-usługowe w rozumieniu PKOB. Podkreślenia wymaga, że PKOB nie nazywa budynkami usługowymi budynków użyteczności publicznej, a także budynków kultury fizycznej oraz przeznaczonych do organizowania imprez sportowych. Moga to być również obiekty, w których prowadzi się działalność wymienioną w rozporządzeniu w sprawie Polskiej Klasyfikacji Wyrobów i Usług (PKWiU), albo w rozporządzeniu w sprawie Polskiej Klasyfikacji Działalności (PKD).

Podobnych problemów nastręcza ustalenie czym są obiekty budowlane, w których się coś produkuje. Moga to być budynki przemysłowe i magazynowe w rozumieniu PKOB. Moga to być również obiekty, w których prowadzi się działalność wymienioną w rozporządzeniu w sprawie Polskiej Klasyfikacji Wyrobów i Usług (PKWiU) albo w rozporządzeniu w sprawie Polskiej Klasyfikacji Działalności (PKD).

Ustawa Prawo geodezyjne i kartograficzne (ugk) stanowi, że podstawą planowania przestrzennego, wymiaru podatków, oznaczania nieruchomości w księgach wieczystych oraz statystyki publicznej są dane zawarte w ewidencji gruntów i budynków [art. 21 ust. 1 ugk].

Na podstawie tej ustawy wydano rozporządzenie w sprawie ewidencji gruntów i budynków (rozp. eg). Według tego rozporządzenia budynek, to „obiekt budowlany, który jest budynkiem w rozumieniu przepisów ustawy (...) Prawo budowlane" [§ 2 pkt 3 rozp. eg]. Jednocześnie danymi ewidencyjnymi dotyczącymi budynków są „rodzaj budynku według Klasyfikacji Środków Trwałych (KŚT), o której mowa w przepisach wydanych na podstawie (...) ustawy (...) o statystyce publicznej" [§ 18 pkt 3 rozp. eg].

Rozporządzenie w sprawie klasyfikacji środków trwałych (KŚT) stosuje odesłanie do PKOB. Jak już napisano, PKOB inaczej definiuje i grupuje budynki oraz inne obiekty budowlane niż ustawa Prawo budowlane. Oznacza to, że przepisy rozporządzenia w sprawie ewidencji gruntów i budynków są wewnętrznie sprzeczne. 
Tylko pozornie oczywistym wydaje się zastosowanie w planie miejscowym odesłania do definicji budynków, zawartych w ustawie Prawo budowlane i wydanych na jej podstawie przepisach wykonawczych. Środki trwałe, będące budynkami klasyfikuje się zgodnie z PKOB, bo tak stanowi rozporządzenie w sprawie klasyfikacji środków trwałych (KŚT). Jednocześnie, w rozporządzeniu w sprawie ewidencji gruntów i budynków zastosowano odesłanie do KŚT. Stawia to sporządzających plany miejscowe w bardzo trudnej sytuacji. Obydwa powyższe rozporządzenia rzutuja na system podatkowy, a tym samym na ustalenia prognozy skutków finansowych uchwalenia miejscowego planu zagospodarowania przestrzennego. Z kolei, organy wydające pozwolenia na budowę, sprawdzając zgodność planowanej inwestycji z planem miejscowym, posługuja się nazewnictwem z ustawy Prawo budowlane.

Skoro podstawa planowania przestrzennego są dane zawarte w ewidencji gruntów i budynków, to warto przyjrzeć się, jak ta ewidencja klasyfikuje poszczególne tereny, nazywane użytkami gruntowymi (nazwy w formie cytatów). Jedną z podstawowych grup użytków gruntowych są "grunty zabudowane i zurbanizowane”, w których wyodrębnia się "tereny mieszkaniowe”, ,tereny przemysłowe” oraz „inne tereny zabudowane" [§ 9 ust. 3 pkt 1, pkt 2 i pkt 3 rozp. eg]. Szczegółowy opis tych terenów zawiera Załącznik nr 1 do rozporządzenia w sprawie ewidencji gruntów i budynków (dalej Załącznik nr 1 rozp. eg).

Do użytku o nazwie „tereny mieszkaniowe” zalicza się grunty „zajęte pod budynki mieszkalne” oraz „zajęte pod budynki gospodarcze i techniczne, związane funkcjonalnie z budynkami mieszkalnymi”, a także „zajęte pod trawniki, rabaty, kwietniki, warzywniki” [Załącznik nr 1 rozp. eg]. Podkreślenia wymaga, że „tereny mieszkaniowe” nie obejmuja gruntów zajętych pod budynki mieszkalne na gruntach rolnych, czyli wielu budynków na wsiach. Takie budynki wchodzą w skład użytku o nazwie "grunty rolne zabudowane" [Załącznik nr 1 rozp. eg].

Do użytku o nazwie „tereny przemysłowe” zalicza się grunty „zajęte pod budynki przemysłowe lub magazynowe oraz związane z tymi budynkami budowle i urządzenia, w szczególności: wiaty, kotłownie, zbiorniki, przewody naziemne, place składowe, place postojowe i manewrowe, ogrodzenia, śmietniki, składowiska odpadów”, a także „zajęte pod rabaty i kwietniki" [Załącznik nr 1 rozp. eg].

Do użytku o nazwie „inne tereny zabudowane” zalicza się grunty „zajęte pod budynki inne niż mieszkalne, przemysłowe lub magazynowe oraz budowle lub urządzenia związane z tymi budynkami, w szczególności: kotłownie, zbiorniki, przewody naziemne, place składowe, place postojowe i manewrowe, ogrodzenia, śmietniki, składowiska odpadów (...) rabaty i kwietniki", a także „zajęte pod cmentarze czynne oraz cmentarze nieczynne" [Załącznik nr 1 rozp. eg].

W przeciwieństwie do Załącznika nr 1 do rozp. mpzp, Załącznik nr 1 rozp. eg precyzyjnie określa, co wchodzi w skład wymienionych w nim terenów (użytków gruntowych). Podkreślenia wymaga, że wszystkie trzy opisane powyżej użytki gruntowe to grunty nie tylko pod obiektami budowlanymi, ale i grunty pokryte roślinnością towarzysząca tym obiektom. 
Natomiast Załącznik nr 1 do rozp. mpzp nie precyzuje, czy na terenach o nazwach „Tereny zabudowy mieszkaniowej”, „Tereny zabudowy usługowej” i „Tereny zabudowy techniczno-produkcyjnej" mają być tylko obiekty budowlane, czy również roślinność im towarzysząca. Na rysunku planu miejscowego dopuszcza się stosowanie „uzupełniających i mieszanych oznaczeń” [§ 9 pkt 4 rozp. mpzp], co wskazywałoby, że jeśli chce się mieć rośliny na powyższych terenach, to trzeba $\mathrm{w}$ ich nazwach dodać podgrupę „Tereny zieleni urządzonej..." (symbol ZP) i zastosować oznaczenia, np.: MN/ZP, U/ZP, P/ZP. Praktyka sporządzania planów miejscowych wskazuje na różne podejście - zastosowanie symbolu mieszanego albo wprowadzenie w tekście uchwały ustalenia dotyczącego zieleni. Można również uznać za oczywiste, że obiektom budowlanym towarzyszą rośliny, skoro trzeba określać powierzchnię biologicznie czynną terenów.

Z niezrozumiałych względów Załącznik nr 1 do rozp. mpzp w grupie „Tereny zabudowy techniczno-produkcyjnej" wyodrębnia podgrupę o nazwie "Obszary i tereny górni-

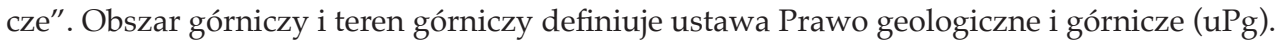
Na podstawie tej ustawy ustala się ich położenie, niezależnie od autorów projektu planu miejscowego.

Obszar górniczy, to „przestrzeń, w granicach której przedsiębiorca jest uprawniony do wydobywania kopaliny, podziemnego bezzbiornikowego magazynowania substancji, podziemnego składowania odpadów, podziemnego składowania dwutlenku węgla oraz prowadzenia robót górniczych niezbędnych do wykonywania koncesji” [art. 6 ust. 1 pkt 5 uPg].

Teren górniczy, to „przestrzeń objęta przewidywanymi szkodliwymi wpływami robót górniczych zakładu górniczego" [art. 6 ust. 1 pkt 15 uPg].

Wydaje się, że powyższe pojęcia określają nie tyle przeznaczenie terenu, ile są informacją o uwarunkowaniach, z których to przeznaczenie powinno wynikać, np. na tych terenach nie powinno być budynków mieszkalnych, ale zapewne moga być obiekty budowlane służace produkcji związanej np. z węglem.

Ponadto, skoro w Załączniku nr 1 do rozp. mpzp użyto nazwy „Obszary i tereny górnicze", to nie wiadomo czy to pojęcie wolno definiować przez odesłanie do ustawy Prawo geologiczne i górnicze. Można się spotkać z zarzutem, że „Obszary i tereny górnicze”, to nie to samo co obszar górniczy oraz teren górniczy w rozumieniu powyższej ustawy, ponieważ to określenia bliskoznaczne.

\section{„Tereny komunikacji" i „Tereny infrastruktury technicznej" [Załącznik nr 1 do rozp. mpzp]}

Ustawa o planowaniu i zagospodarowaniu przestrzennym definiuje pojęcie uzbrojenie terenu. To „drogi, obiekty budowlane, urządzenia i przewody, o których mowa w art. 143 ust. 2 ustawy (...) o gospodarce nieruchomościami" [art. 2 pkt 13 upzp]. Ustawa o gospodarce nieruchomościami (ugn) stanowi: „Przez budowę urządzeń infrastruktury technicznej rozumie się budowę drogi oraz wybudowanie pod ziemia, na ziemi albo nad ziemia przewodów lub urządzeń wodociagowych, kanalizacyjnych, ciepłowniczych, elektrycznych, gazowych 
i telekomunikacyjnych" [art. 143 ust. 2 ugn]. Z powyższego wynika, że drogi to urządzenia infrastruktury technicznej. Tymczasem Załącznik nr 1 do rozp. mpzp wyraźnie odróżnia od siebie „Tereny komunikacji” oraz „Tereny infrastruktury technicznej”.

Ustawa o drogach publicznych (udp), definiuje czym są drogi, dzieląc je na drogi publiczne i drogi wewnętrzne [art. 1 i art. 8 ust. 1 udp] oraz określa kategorie dróg publicznych: drogi krajowe, wojewódzkie, powiatowe i gminne.

Rozporządzenie w sprawie warunków technicznych, jakim powinny odpowiadać drogi publiczne i ich usytuowanie (rozp. d.p.) definiuje pojęcie klasa drogi publicznej, to „przyporządkowanie drodze odpowiednich parametrów technicznych, wynikających z jej cech funkcjonalnych" [§ 3 pkt 4 rozp. d.p.] oraz ustala klasy dróg i ich hierarchię: autostrady, ekspresowe, główne ruchu przyspieszonego, główne, zbiorcze, lokalne i dojazdowe [§ 4 ust. 1 rozp. d.p.]. Ponadto rozporządzenie określa, której kategorii dróg publicznych dotyczą poszczególne klasy [§ 4 ust. 2 rozp. d.p.].

W rozumieniu ustawy Prawo budowlane drogi oraz przewody wodociagowe, kanalizacyjne, ciepłownicze, elektryczne, gazowe i telekomunikacyjne to budowle [art. 3 pkt $3 \mathrm{uPb}$ ].

Ustawa Prawo wodne $(\mathrm{uPw})$ stanowi, że wody śródlądowe moga służyć transportowi i prócz gruntów pod wodami obejmują obiekty budowlane funkcjonalnie z nim powiązane [art. 193 ust. 1 i ust. 5 pkt 3 uPw]. Nie wiadomo, czy stosując w Załączniku nr 1 do rozp. mpzp nazwę „Tereny komunikacji wodnej, szlaki wodne” ustawodawca miał na myśli śródlądowe drogi wodne, o których mowa w ustawie Prawo wodne.

Według rozporządzenia w sprawie ewidencji gruntów i budynków "tereny komunikacyjne”, to "drogi”, "tereny kolejowe” oraz „inne tereny komunikacyjne” [§ 9 ust. 3 pkt 7 rozp. eg]. Szczegółowy opis tych terenów zawiera Załącznik nr 1 rozp. eg.

Rozbieżność między nazwami terenów według Załącznika nr 1 do rozp. mpzp a pojęciem uzbrojenie terenu w rozumieniu ustawy o planowaniu i zagospodarowaniu przestrzennym (z odesłaniem do ustawy o gospodarce nieruchomościami), prowadzi do chaosu przy sporządzaniu planów miejscowych. W szczególności utrudnia przygotowanie wymaganego prawem załącznika do uchwały w sprawie uchwalenia takiego planu. Powyższy załącznik określa sposób realizacji zapisanych w planie inwestycji z „zakresu infrastruktury technicznej” [art. 20 ust. 1 upzp]. Nie wiadomo, czy można umieszczać w nim drogi.

\section{„Tereny użytkowane rolniczo" [Załącznik nr 1 do rozp. mpzp]}

Załącznik nr 1 do rozp. mpzp dzieli „Tereny użytkowane rolniczo” na trzy podgrupy, z których dwie sa przeznaczone pod obiekty budowlane związane funkcjonowaniem gospodarstw rolnych. Należy przypuszczać, że „Tereny rolnicze” (trzecia z podgrup) służą wyłącznie uprawom roślin, ale to tylko domniemanie.

Ustawa o planowaniu i zagospodarowaniu przestrzennym nie definiuje powyższych nazw. Co gorsze, wprowadza pojecie grunty rolne i nakazuje uzyskanie zgody „na zmianę przeznaczenia gruntów rolnych i leśnych na cele nierolnicze i nieleśne, jeżeli wymagają tego 
przepisy odrębne" [art. 17 pkt 6 ppkt c upzp]. Przepis odrębny to ustawa o ochronie gruntów rolnych i leśnych (ugrl), wg której gruntami rolnymi są grunty:

„1) określone w ewidencji gruntów jako użytki rolne;

2) pod stawami rybnymi i innymi zbiornikami wodnymi, służącymi wyłącznie dla potrzeb rolnictwa;

3) pod wchodzącymi w skład gospodarstw rolnych budynkami mieszkalnymi oraz innymi budynkami i urządzeniami służącymi wyłącznie produkcji rolniczej oraz przetwórstwu rolno-spożywczemu;

4) pod budynkami i urządzeniami służącymi bezpośrednio do produkcji rolniczej uznanej za dział specjalny, stosownie do przepisów o podatku dochodowym od osób fizycznych i podatku dochodowym od osób prawnych;

5) parków wiejskich oraz pod zadrzewieniami i zakrzewieniami śródpolnymi, w tym również pod pasami przeciwwietrznymi i urządzeniami przeciwerozyjnymi;

6) rodzinnych ogrodów działkowych i ogrodów botanicznych;

7) pod urządzeniami: melioracji wodnych, przeciwpowodziowych i przeciwpożarowych, zaopatrzenia rolnictwa $\mathrm{w}$ wodę, kanalizacji oraz utylizacji ścieków i odpadów dla potrzeb rolnictwa i mieszkańców wsi;

8) zrekultywowane dla potrzeb rolnictwa;

9) torfowisk i oczek wodnych;

10) pod drogami dojazdowymi do gruntów rolnych" [art.2 ust. 1 ugrl].

Według rozporządzenia w sprawie ewidencji gruntów i budynków "grunty rolne" to "użytki rolne”, w tym: "grunty orne”, „łąki trwałe”, "pastwiska trwałe”, „sady”, "grunty rolne zabudowane", , grunty zadrzewione i zakrzewione na użytkach rolnych", ,grunty pod stawami”, „grunty pod rowami” oraz „nieużytki” [§ 9 ust. 1 rozp. eg]. Szczegółowy opis zawiera Załącznik nr 1 rozp. eg.

Nie wiadomo, czy stosując w Załączniku nr 1 do rozp. mpzp nazwy „Tereny obsługi produkcji w gospodarstwach rolnych, hodowlanych, ogrodniczych oraz gospodarstwach leśnych i rybackich” oraz „Tereny zabudowy zagrodowej w gospodarstwach rolnych, hodowlanych, ogrodniczych” ustawodawca miał na myśli grunty „pod wchodzącymi w skład gospodarstw rolnych budynkami mieszkalnymi oraz innymi budynkami i urządzeniami służącymi wyłącznie produkcji rolniczej oraz przetwórstwu rolno-spożywczemu" [art. 2 ust. 1 pkt 3 ugrl] oraz grunty „pod budynkami i urządzeniami służącymi bezpośrednio do produkcji rolniczej uznanej za dział specjalny, stosownie do przepisów o podatku dochodowym od osób fizycznych i podatku dochodowym od osób prawnych" [art.2 ust. 1 pkt 4 ugrl].

Nie wiadomo, czy powyższe grunty, to "grunty rolne zabudowane" w rozumieniu rozporządzenia w sprawie ewidencji gruntów i budynków.

Nie wiadomo również, jak się ma do tego zabudowa zagrodowa, o której mowa w przepisie wykonawczym do ustawy Prawo budowlane [§ 3 pkt 3 rozp.w.t.].

Nadmiar określeń bliskoznacznych i wynikających z nich powtórzeń prowadzi do chaosu. W szczególności utrudnia opracowanie wniosku o wydanie zgody na zmianę przeznaczenia gruntów rolnych na cele nierolnicze. 


\section{„Tereny zieleni i wód" [Załącznik nr 1 do rozp. mpzp]}

Załącznik nr 1 do rozp. mpzp dzieli „,Tereny zieleni i wód” na osiem podgrup. Powyższych terenów dotyczy szereg aktów prawa, z których najistotniejsze to ustawa o ochronie przyrody (uop) i ustawa Prawo wodne.

Terenami zieleni sa ,tereny urządzone wraz z infrastruktura techniczną i budynkami funkcjonalnie z nimi związanymi, pokryte roślinnościa, pełniące funkcje publiczne, a w szczególności parki, zieleńce, promenady, bulwary, ogrody botaniczne, zoologiczne, jordanowskie i zabytkowe, cmentarze, zieleń towarzyszaca drogom na terenie zabudowy, placom, zabytkowym fortyfikacjom, budynkom, składowiskom, lotniskom, dworcom kolejowym oraz obiektom przemysłowym" [art. 5 pkt 21 uop].

Pojęcie tereny zieleni występuje nie tylko w nazwie grupy „Tereny zieleni i wód”, ale również $\mathrm{w}$ nazwach dwóch podgrup wymienionych w Załączniku nr 1 do rozp. mpzp: „Tereny zieleni objęte formami ochrony przyrody zgodnie z przepisami o ochronie przyrody” oraz „Tereny zieleni urządzonej..."

Można domniemywać, że „Tereny zieleni objęte formami ochrony przyrody zgodnie z przepisami o ochronie przyrody", to tereny zieleni [art. 5 pkt 21 uop] położone na obszarach objętych tymi formami ochrony. Formami ochrony przyrody są: parki narodowe, rezerwaty przyrody, parki krajobrazowe, obszary chronionego krajobrazu, obszary Natura 2000, pomniki przyrody, stanowiska dokumentacyjne, użytki ekologiczne, zespoły przyrodniczo-krajobrazowe oraz ochrona gatunkowa roślin, zwierząt i grzybów" [art. 6 ust. 1 uop]. Położenie tych obszarów oraz zasady ich funkcjonowania ustalają ustawa o ochronie przyrody i wydane na jej podstawie przepisy wykonawcze oraz dokumenty, niezależnie od planu miejscowego.

Wydaje się, że wprowadzając do Załącznika nr 1 do rozp. mpzp pojęcie „Tereny zieleni objęte formami ochrony przyrody..." ustawodawca chciał określić nie tyle przeznaczenie tych terenów w planie miejscowym, ile przekazać informację o uwarunkowaniach, z których to przeznaczenie powinno wynikać.

„Tereny zieleni urządzonej...", to np.:

- ogrody botaniczne traktowane jako tereny zieleni w rozumieniu ustawy o ochronie przyrody [art. 5 pkt 21 uop] albo jako grunty rolne [art.2 ust. 1 pkt 6 ugrl];

- grodziska, kurhany, zabytkowe fortyfikacje, czyli zabytki w rozumieniu ustawy o ochronie zabytków i opiece nad zabytkami (uoz) [art. 3 pkt 1 oraz art. 6 uoz];

- zieleń towarzysząca obiektom budowlanym.

Według rozporządzenia w sprawie ewidencji gruntów i budynków zieleń, która towarzyszy obiektom budowlanym wchodzi w skład użytków gruntowych o nazwie "tereny mieszkaniowe”, "tereny przemysłowe” oraz „inne tereny zabudowane” [§ 9 ust. 3 pkt 1 , pkt 2 i pkt 3 rozp. eg oraz Załącznik nr 1 rozp. eg].

W Załączniku nr 1 do rozp. mpzp o wodach jest mowa w nazwie grupy „Tereny zieleni i wód” oraz w nazwach dwóch podgrup: „Tereny wód powierzchniowych morskich” oraz „Tereny wód powierzchniowych śródlądowych (rzeki, jeziora, stawy, strumienie, kanały)”. 
Nazwy te są określeniami bliskoznacznymi do pojęć użytych w ustawie Prawo wodne oraz ewidencji gruntów i budynków.

Grunty pokryte wodami, to „grunty tworzace dna i brzegi cieków naturalnych, jezior oraz innych naturalnych zbiorników wodnych w granicach linii brzegu, a także grunty wchodzące w skład sztucznych zbiorników wodnych, stopni wodnych oraz jezior podpiętrzonych, będące gruntami pokrytymi wodami powierzchniowymi przed wykonaniem urządzeń piętrzących" [art. 16 pkt $16 \mathrm{uPw}$ ].

Wodami powierzchniowymi sa „,wody morza terytorialnego, morskie wody wewnętrzne oraz śródlądowe wody powierzchniowe" [art. $20 \mathrm{uPw}$ ].

Śródlądowe wody powierzchniowe, to śródlądowe wody płynące, czyli „wody w ciekach naturalnych, jeziorach oraz sztucznych zbiornikach wodnych usytuowanych na wodach płynących i kanałach" [art. 22 uPw] oraz śródlądowe wody stojące, czyli wody „w jeziorach oraz innych naturalnych zbiornikach wodnych niezwiązanych bezpośrednio (...) z powierzchniowymi śródlądowymi wodami płynacymi" [art. 23 ust. $1 \mathrm{uPw}$ ].

Jednym z użytków gruntowych sa „grunty pod wodami” [§ 8 ust. 1 pkt 4 rozp. eg], w których wyodrębnia się "grunty pod morskimi wodami wewnętrznymi", ,grunty pod wodami powierzchniowymi płynącymi" oraz "grunty pod wodami powierzchniowymi stojącymi" [§ 9 ust. 4 rozp. eg]. Szczegółowy opis zawiera Załącznik nr 1 rozp. eg.

Jeśli przyjać, że pod pojęciem „Tereny wód powierzchniowych morskich” ustawodawca miał na myśli wody morza terytorialnego, morskie wody wewnętrzne, to dla tych wód nie sporządza się planów miejscowych [art. 4 ust. 1a upzp], a tym samym nie ma potrzeby ustalania ich przeznaczenia.

Ustawa Prawo wodne wyróżnia obszary narażone na niebezpieczeństwo powodzi, na których istnieje znaczące ryzyko powodzi [art. 16 pkt $33 \mathrm{uPw}$ ] oraz obszary szczególnego zagrożenia powodzia, na których prawdopodobieństwo wystapienia powodzi wynosi od $1 \%$ do $10 \%$ [art. 16 pkt $34 \mathrm{uPw}$ ].

Nie wiadomo, czy „Obszary zagrożone powodzią” w rozumieniu Załącznika nr 1 do rozp. mpzp, to obydwa te obszary, czy tylko np. obszary szczególnego zagrożenia powodzią. Nazwa tego terenu określa nie tyle jego przeznaczenie, ile jest informacją o uwarunkowaniach, z których to przeznaczenie powinno wynikać.

Z niezrozumiałych względów podgrupa „Tereny ogrodów działkowych” znalazła się w grupie „Tereny zieleni i wód”, a nie w grupie „Tereny użytkowane rolniczo”. W rozumieniu ustawy o ochronie gruntów rolnych i leśnych gruntami rolnymi, sa grunty „rodzinnych ogrodów działkowych" [art.2 ust. 1pkt 6 ugrl]. Nie do końca wiadomo, o jakie ogrody działkowe chodzi.

Również podgrupa „Cmentarze” nie pasuje do grupy „Tereny zieleni i wód”. To wprawdzie tereny zieleni $\mathrm{w}$ rozumieniu ustawy o ochronie przyrody, ale budowle $\mathrm{w}$ rozumieniu ustawy Prawo budowlane. [art.3 pkt 3 uPb]. Co więcej, przepisy dotyczące cmentarzy zezwalają na lokalizację w ich granicach budynków. W rozumieniu ewidencji gruntów i budynków to „inne tereny zabudowane” [§ 9 ust. 3 pkt 3 rozp. eg oraz Załącznik nr 1 rozp. eg].

Wydaje się, że jedynie nazwę podgrupy „Lasy” można próbować definiować poprzez odesłanie do ustawy o lasach (uL). Lasem w rozumieniu tej ustawy jest grunt: 
„1) o zwartej powierzchni co najmniej 0,10 ha, pokryty roślinnością leśna (uprawami leśnymi) - drzewami i krzewami oraz runem leśnym - lub przejściowo jej pozbawiony:

a) przeznaczony do produkcji leśnej lub

b) stanowiacy rezerwat przyrody lub wchodzacy w skład parku narodowego albo

c) wpisany do rejestru zabytków;

2) związany z gospodarką leśna, zajęty pod wykorzystywane dla potrzeb gospodarki leśnej: budynki i budowle, urządzenia melioracji wodnych, linie podziału przestrzennego lasu, drogi leśne, tereny pod liniami energetycznymi, szkółki leśne, miejsca składowania drewna, a także wykorzystywany na parkingi leśne i urządzenia turystyczne" [art. 3 pkt 1 i pkt 2 uL].

Należy pamiętać, że w polskim systemie prawnym występuje również pojęcie grunty leśne. W rozumieniu ustawy o ochronie gruntów rolnych i leśnych, są to grunty: „określone jako lasy w przepisach o lasach”, ,zrekultywowane dla potrzeb gospodarki leśnej”, „pod drogami dojazdowymi do gruntów leśnych" [art. 2 ust. 2 ugrl].

Jedną z grup użytków gruntowych, wykazywanych w ewidencji gruntów i budynków są "grunty leśne oraz zadrzewione i zakrzewione” [§ 8 ust. 1 pkt 2 rozp. eg]. Grunty, te dziela się na: "lasy", "grunty zadrzewione i zakrzewione” oraz "grunty pod rowami” [§ 9 ust. 2 rozp. eg]. „Do lasów zalicza się grunty określone jako „las” w ustawie (...) o lasach” [Załącznik nr 1 rozp. eg].

Nadmiar określeń bliskoznacznych prowadzi do chaosu. Warto zwrócić uwagę, że w świetle przepisów odrębnych, na terenach wymienionych w grupie „Tereny zieleni i wód” moga występować obiekty budowlane. Nie wiadomo, czy ustawodawca tego chciał, czy po prostu tak wyszło.

\section{Podsumowanie}

Analiza Załącznika nr 1 do rozp. mpzp potwierdza konkluzje zawarte w artykule pt. Ksztattowanie przestrzeni - sprawny system czy chaos? Miejscowy plan zagospodarowania przestrzennego - zakres stanowienia. Zakres stanowienia jest mało precyzyjny, ponieważ brakuje definicji użytych w nim pojęć w ustawie o planowaniu i zagospodarowaniu przestrzennym oraz $\mathrm{w}$ rozporządzeniu $\mathrm{w}$ sprawie wymaganego zakresu projektu miejscowego planu zagospodarowania. Wieloznaczne nazwy terenów umieszczonych w Załączniku nr 1 nie ułatwiaja, a utrudniają sporządzanie planów miejscowych. Chaos pogłębiają określenia bliskoznaczne zawarte w przepisach odrębnych.

Wydaje się, że przeznaczenie terenu/ów można rozumieć jako informację o tym, jaki rodzaj zabudowy oraz co prócz zabudowy może istnieć i powstać na danym terenie - wody oraz zieleń, czyli rośliny.

Pojęcie zabudowa, wymaga opracowania jednoznacznej definicji i stosowania jej we wszystkich aktach prawa. Jeśli przyjać, że oznacza obiekty budowlane (budynki, budowle i obiekty małej architektury) oraz urządzenia budowlane, to również te pojęcia powinny mieć jedną definicję w całym polskim systemie prawnym. 
Jednakowe definicje powinny mieć również tereny związane z rolnictwem, lasami i wodami.

W Załączniku nr 1 do rozp. mpzp mieszają się tereny, które sporządzający plan miejscowy ma prawo wyznaczyć, z terenami, których istnienie jest niezależne od sporządzającego plan, bo wynika z przepisów odrębnych. Przykładowo, na obszarze górniczym mogą występować składy i magazyny. Na terenach objętych formami ochrony przyrody (np. w parkach krajobrazowych) oraz w lasach często istnieją budynki mieszkalne jednorodzinne, np. leśniczówki. Formy ochrony przyrody mogą obejmować obszary narażone na niebezpieczeństwo powodzi.

Warto zastanowić się nad powiązaniem nazw terenów w planach miejscowych z określeniami występującymi w ewidencji gruntów i budynków. Może ukróciłoby to nadmiar określeń bliskoznacznych w polskim systemie prawnym.

Załącznik nr 1 do rozporządzenia w sprawie wymaganego zakresu projektu miejscowego planu zagospodarowania przestrzennego pt. „Podstawowe barwne oznaczenia graficzne i literowe dotyczące przeznaczenia terenów, które należy stosować na projekcie rysunku planu miejscowego (wzór)" - wyciąg (w skrócie Załącznik nr 1 do rozp. mpzp)

1. Tereny zabudowy mieszkaniowej

1.1. Tereny zabudowy mieszkaniowej jednorodzinnej-MN

1.2. Tereny zabudowy mieszkaniowej wielorodzinnej-MW

2. Tereny zabudowy usługowej

2.1. Tereny zabudowy usługowej-U

2.2. Tereny sportu i rekreacji - US

2.3. Tereny rozmieszczenia obiektów handlowych o powierzchni sprzedaży powyżej $2000 \mathrm{~m}^{2}$ - UC

3. Tereny użytkowane rolniczo

3.1. Tereny rolnicze $-\mathrm{R}$

3.2. Tereny obsługi produkcji w gospodarstwach rolnych, hodowlanych, ogrodniczych oraz gospodarstwach leśnych i rybackich - RU

3.3. Tereny zabudowy zagrodowej w gospodarstwach rolnych, hodowlanych, ogrodniczych - RM

4. Tereny zabudowy techniczno-produkcyjnej

4.1. Tereny obiektów produkcyjnych, składów i magazynów - P

4.2. Obszary i tereny górnicze - PG

5. Tereny zieleni i wód

5.1. Tereny zieleni objęte formami ochrony przyrody zgodnie z przepisami o ochronie przyrody $-\mathrm{ZN}$

5.2. Lasy - ZL

5.3. Tereny zieleni urządzonej, takie jak: parki, ogrody, zieleń towarzysząca obiektom budowlanym,zieleńce, arboreta, alpinaria, grodziska, kurhany, zabytkowe fortyfikacje - ZP 
5.4. Tereny ogrodów działkowych - ZD

5.5. Cmentarze - ZC

5.6. Obszary zagrożone powodzią - ZZ

5.7. Tereny wód powierzchniowych morskich - WM

5.8. Tereny wód powierzchniowych śródlądowych (rzeki, jeziora, stawy, strumienie, kanały) - WS

6. Tereny komunikacji

6.1. Tereny dróg publicznych - KD

6.2. Tereny dróg wewnętrznych - KDW

6.3. Tereny komunikacji wodnej, szlaki wodne - KW

7. Tereny infrastruktury technicznej

7.1. Elektroenergetyka - E

7.2. Gazownictwo - G

7.3. Wodociagi $-\mathrm{W}$

7.4. Kanalizacja - K

7.5. Telekomunikacja - T

7.6. Gospodarowanie odpadami - O

7.7. Ciepłownictwo - C

Nazwy terenów, ich oznaczenia literowe oraz liczba porządkowa to cytaty.

\section{Materiały źródłowe}

Ustawy:

Ustawa z dnia 21 marca 1985 r. o drogach publicznych (t.j. z dnia 25 czerwca 2021 r. Dz.U. z 2021 r. poz. 1376 z późn. zm.), w skrócie udp.

Ustawa z dnia 17 maja 1989 r. Prawo geodezyjne i kartograficzne (t.j. z dnia 1 października 2021 r. Dz.U. z 2021 r. poz. 1990 z późn. zm.), w skrócie ugk

Ustawa z dnia 28 września 1991 r. o lasach (t.j. z dnia 16 czerwca 2021 r. Dz.U. z 2021 r. poz. 1275), w skrócie uL.

Ustawa z dnia 7 lipca 1994 r. Prawo budowlane (t.j. z dnia 7 lipca 2020 r. Dz.U. z 2020 r. poz. 1333 z późn. zm.), w skrócie uPb.

Ustawa z dnia 3 lutego 1995 r. o ochronie gruntów rolnych i leśnych (t.j. z dnia 2 lipca 2021 r. Dz.U. z 2021 r. poz. 1326), w skrócie ugrl.

Ustawa z dnia 21 sierpnia 1997 r. o gospodarce nieruchomościami (t.j. z dnia 17 września 2021 r. Dz.U. z 2021 r. poz. 1899), w skrócie ugn.

Ustawa z dnia 27 marca 2003 r. o planowaniu i zagospodarowaniu przestrzennym (t.j. z dnia 31 marca 2021 r. Dz.U. z 2021 r. poz. 741 z późn. zm.), w skrócie upzp. 
Ustawa z dnia 23 lipca 2003 r. o ochronie zabytków i opiece nad zabytkami (t.j. z dnia 19 marca 2021 r. Dz.U. z 2021 r. poz. 710 z późn. zm.), w skrócie uoz.

Ustawa z dnia 16 kwietnia 2004 r. o ochronie przyrody (t.j. z dnia 18 maja 2021 r. Dz.U. z 2021 r. poz. 1098), w skrócie uop.

Ustawa z dnia 9 czerwca 2011 r. Prawo geologiczne i górnicze (t.j. z dnia 2 lipca 2021 r. Dz.U. z 2021 r. poz. 1420 z późn. zm.), w skrócie uPg.

Ustawa z dnia 20 lipca 2017 r. Prawo wodne (t.j. z dnia 1 marca 2021 r. Dz.U. z 2021 r. poz. 624 z późn. zm.), w skrócie uPw.

Rozporządzenia:

Rozporządzenie Ministra Transportu i Gospodarki Morskiej z dnia 2 marca 1999 r. w sprawie warunków technicznych, jakim powinny odpowiadać drogi publiczne i ich usytuowanie (t.j. z dnia 23 grudnia 2015 r. Dz.U. z 2016 r. poz. 124 z późn. zm.), w skrócie rozp.d.p.

Rozporządzenia Rady Ministrów z dnia 30 grudnia 1999 r. w sprawie Polskiej Klasyfikacji Obiektów Budowlanych (PKOB) (Dz.U. nr 112, poz. 1316 z późn. zm.), w skrócie PKOB.

Rozporządzenie Ministra Infrastruktury z dnia 12 kwietnia 2002 r. w sprawie warunków technicznych jakim powinny odpowiadać budynki i ich usytuowanie (t.j. z 8 kwietnia $2019 \mathrm{r}$. Dz.U. z 2019 r. poz. 1065 z późn. zm.), w skrócie rozp.w.t.

Rozporządzenie Prezesa Rady Ministrów z dnia 20 czerwca 2002 r. w sprawie Zasad techniki prawodawczej (t.j. z dnia 29 lutego 2016 r. Dz.U. z 2016 r. poz. 283) w skrócie rozp.ztp.

Rozporządzenie Ministra Infrastruktury z dnia 26 sierpnia 2003 r. w sprawie wymaganego zakresu projektu miejscowego planu zagospodarowania przestrzennego (Dz.U. nr 164 z 2003 r. poz. 1587), w skrócie rozp. mpzp.

Rozporządzenie Rady Ministrów z dnia 24 grudnia 2007 r. w sprawie Polskiej Klasyfikacji Działalności (PKD) (Dz.U. nr 251, poz. 1885 z późn. zm.), w skrócie PKD.

Rozporządzenie Rady Ministrów z dnia 4 września 2015 r. w sprawie Polskiej Klasyfikacji Wyrobów i Usług (PKWiU) (Dz.U. z 2015 r. poz. 1676 z późn. zm.), w skrócie PKWiU.

Rozporządzenie Rady Ministrów z dnia 3 października 2016 r. w sprawie klasyfikacji środków trwałych (KŚT) (Dz.U. z 2016 r. poz. 1864), w skrócie KŚT.

Rozporządzenie Ministra Rozwoju, Pracy i Technologii z dnia 27 lipca 2021 r. w sprawie ewidencji gruntów i budynków (Dz.U. z 2021 r. poz. 1390), w skrócie rozp. eg. 


\section{Imposing spatial order - an efficient system or chaos? Local spatial development plan - land use}

\section{ABSTRACT}

This paper is another in a series of articles on the spatial planning system in Poland and the second of three on the scope of constituting local spatial development plans. It supplements and extends the article entitled Imposing spatial order - an efficient system or chaos? Local spatial development plan - the scope of regulation. It relates to the key issue which is the land use. It indicates the ambiguity of this concept, and thus the imprecise scope of drawing up the local plans.

Some text excerpts of the article Imposing spatial order - an efficient system or chaos? Local spatial development plan - the scope of regulation. were deliberately repeated. For those who have not read it, this will help understand the issues discussed in this article.

In order to maintain the precision of the statement, a number of quotations have been used. The article is based on the law in force at the end of October 2021.

Key words: local spatial development plan, land use

\footnotetext{
Anna Wieczorek - na Politechnice Warszawskiej ukończyła Wydział Architektury, Podyplomowe Studium Urbanistyki, Studium Doskonalenia Pedagogicznego oraz uzyskała dyplom doktora nauk technicznych. Posiada uprawnienia do projektowania w planowaniu przestrzennym oraz uprawnienia do pełnienia samodzielnych funkcji technicznych w budownictwie. Specjalizuje się w wykonywaniu projektów miejscowych planów zagospodarowania przestrzennego (główny projektant ponad 30 uchwalonych projektów planów miejscowych) oraz projektów studiów uwarunkowań i kierunków zagospodarowania przestrzennego gmin (główny projektant 5 uchwalonych studiów). Ma doświadczenie w pracy ze studentami - na Politechnice Warszawskiej i w Wyższej Szkole Przedsiębiorczości i Administracji w Lublinie. Należy do Mazowieckiej Okręgowej Izby Architektów z siedzibq w Warszawie oraz Pan-Europejskiej Federacji Ochrony Zabytków - Europa Nostra z siedzibq w Holandii.

Anna Wieczorek - graduate of the Warsaw University of Technology - Faculty of Architecture, Postgraduate Town Planning Studies, Pedagogical Study, PhD in technical science. Holds professional permits for spatial planning and is authorised to perform independent technical functions in construction. Specialises in the preparation of local spatial development plans (is the main designer of more than 30 approved local development plans) and draft studies of conditions and directions of the spatial development of municipalities (main designer of 5 approved studies). Has experience in working with students - at the Warsaw University of Technology and the University College of Enterprise and Administration in Lublin. Member of the Warsaw-based Masovian Chamber of Architects and the Pan-European Federation for Cultural Heritage, Europa Nostra based in the Netherlands.
} 
